Author version: Paleoceanography, vol.28(3); 2013; 413-425

\title{
Variation in the Indian Summer Monsoon intensity during the Bølling-Ållerød and Holocene
}

\author{
Pratima M. Kessarkar*, V. Purnachadra Rao, S. W. A. Naqvi, Supriya G. Karapurkar \\ National Institute of Oceanography, Council of Scientific and Industrial Research, Dona Paula, Goa 403004 \\ * Corresponding author (Pratima M. Kessarkar); E-mail: pratimak@nio.org
}

\begin{abstract}
Variations in the Indian summer monsoon (ISM) intensity during the last 16.7 ka have been studied using organic carbon $\left(\mathrm{C}_{\mathrm{org}}\right), \delta^{15} \mathrm{~N}$ of sedimentary organic matter, $\mathrm{CaCO}_{3}$, sediment texture, $\delta^{18} \mathrm{O}_{\mathrm{C}}$ and $\mathrm{Mg} / \mathrm{Ca}$ derived sea surface temperature, $\delta^{18} \mathrm{O}$ of sea water and sea surface salinity, in a ${ }^{14} \mathrm{C}$-dated sediment core from the eastern Arabian Sea. The $\delta^{18} \mathrm{O}$ in water and planktonic foraminifera shells off the central west coast of India may be controlled by the ISM intensity as this area receives high precipitation and land runoff. Also, the $\mathrm{C}_{\text {org }}$ and $\mathrm{CaCO}_{3}$ contents of sediments and $\delta^{15} \mathrm{~N}$ of sedimentary organic matter may be linked to ISM-induced productivity and denitrification. The results of the present study reveal that between 16 and 15.2 ka BP the ISM was weak with minor fluctuations and started intensifying around $15.2 \mathrm{ka} \mathrm{BP}$, at the onset of the Bølling-Ållerød (B-A) event. The B-A event is characterized by higher water column denitrification rates comparable to the present day. The ISM signatures observed in the $\delta^{18} \mathrm{O}_{\mathrm{C}}$ record of $\mathrm{B}-\mathrm{A}$ event compare well with those from Timta cave of the western Himalayas and also the Asian summer monsoon signatures from the Hulu caves in China and warming signatures in Greenland Ice Sheet Project 2 (GISP2) suggesting atmospheric tele-connections through Intertropical Convergence Zone (ITCZ). The boundary between the Younger Dryas and the Holocene is discernible with small episodes of abrupt events of increased ISM intensity. This decrease in $\delta^{18} \mathrm{O}_{\mathrm{C}}$ values at $\sim 11.8 \mathrm{ka} \mathrm{BP}$ is contemporary with June solar insolation maximum at $30^{\circ}$ north and the increase in methane in the GISP2 ice core supporting episodes of warmer climate and increase in ISM intensity. The ISM seems to have been most stable between 7 and $5.6 \mathrm{ka} \mathrm{BP}$. The core exhibits periodicity of 500 that is comparable to the Atlantic water formation and the Chinese monsoon.
\end{abstract}

\section{Key words:}

Monsoon, Bølling-Ållerød, Holocene, India, Arabian Sea, Sediment 


\section{Introduction}

Climatologically, the monsoon regions are important areas on the Earth and are responsible for the transport of major part of global atmospheric heat and moisture [Clemens et al., 2003]. One of the most important of such systems is the Indian Summer Monsoon (ISM). Both modern and paleo- studies in the Indian Ocean have demonstrated that the ISM is highly variable over annual to orbital time scales [e.g. Altabet et al., 1999; Clement et al., 1999; Saji et al., 1999; Clark et al., 2000]. The past ISM intensities and environmental changes observed in proxy records from the Arabian Sea sediments have been related to changes in the Atlantic Ocean [e.g. Suthhof et al., 2001; Altabet et al., 2002] and in the Pacific Ocean [Saraswat et al., 2007] suggesting atmospheric and/or oceanic teleconnections. The ISM is a part of the larger phenomenon, the Asian monsoon, associated with the Intertropical Convergence Zone (ITCZ) which connects the rainfall regions of Asia. Variations in the mean latitudinal position of ITCZ influence tropical and extratropical climate [Fleitmann et al., 2007]. Changes in the ISM rainfall have been observed to be coupled with variations in the East Asian monsoon and the North Atlantic climate [Sinha et al., 2005]. The Holocene ISM records from the Arabian Sea have revealed a link with climate variability over continental China and the South China Sea suggesting simultaneous fluctuations of monsoon intensities in these places [Jung et al., 2004]. The ISM variability during Bølling-Ållerød (B-A) event has been linked to that of the East Asian monsoon [Sinha et al., 2005] based on stalagmite oxygen isotope record from the Timta caves. Staubwasser and Weiss [2006] utilized the data from the Mediterranean and South Asia to compile the abrupt events in these regions and suggested that the ISM became part of the Asian Monsoon since the Holocene time.

The Arabian Sea-based paleo- ISM reconstructions are mostly derived from sediment cores from the northern and western Arabian Sea, with relatively few studies in the eastern Arabian Sea. The ISM proxies used for the northern and western Arabian Sea are mostly upwelling and wind related [e.g. Schulz et al., 1998; Sirocko et al., 1993; Gupta et al., 2003], whereas in the eastern Arabian Sea they are precipitation related like oxygen isotopes, $\mathrm{Mg} / \mathrm{Ca}$ ratios, and terrigenous material [Thamban et al., 2002; Kumar et al., 2005; Anand et al., 2008; Banakar et al., 2010; Rao et al., 2010; Govil and Naidu., 2010; Mahesh et al. 2011]. The high sedimentation rates and varved sediments in the northern Arabian Sea help in deciphering proxy variations of the past at a high temporal resolution. In comparison, because of lower sedimentation rates in the eastern Arabian Sea with consequently coarser temporal resolution fewer proxy records are generated so far [Thamban et al., 2001; Tiwari et al., 2005; Singh et al., 2006; Kessarkar et al., 2007, 2010; Govil and Naidu, 2010; Banakar et al., 2010, Rao et al., 2010] there is a need to study this area to infer past ISM variations on decadal to centennial time scales. There have been a few high resolution studies, though, namely by Agnihotri et al. [2008] off Goa, 
covering the past seven centuries, and by Thamban et al. [2007] that extended to the beginning of the Holocene, which indicated significant fluctuations in the strengths of ISM. The paleoclimatic reconstructions from sediment proxies in the northern Arabian Sea suggest increase in ISM to be associated with the solar insolation maxima. By contrast, the study by Tiwari et al. [2010] in the eastern Arabian Sea suggests strengthening of the ISM during the late Holocene with no link to solar insolation maximum. In view of the above results we selected a core from the southeastern Arabian Sea that receives high monsoon precipitation and runoff during the ISM (Figure $1 \mathrm{~A}-\mathrm{F}$ ) to identify the changes in the strengths of ISM and the abrupt events during the past $16.7 \mathrm{ka}$ BP. We present here surface hydrogrphic change from oxygen isotopes and $\mathrm{Mg} / \mathrm{Ca}$ derived temperature. Further we have combined the new and previously published data to create a robust composite record of the timing and scale of surface hydroclimate change. Comparison is also made with published records of ITCZ linked East Asian monsoon and GISP2 core to explore the link within the Asian monsoon and the dependence of the low-latitude climate on that at high latitudes.

\section{Study Area:}

The ISM is a part of Asian summer monsoon (Figure 1G inset). During June-August the eastern Arabian Sea receives high precipitation and runoff (Figure 1A-F) that depresses salinity of surface waters along the southwest coast of India (southeastern Arabian Sea). These low salinity signatures are reflected in the lower $\delta^{18} \mathrm{O}_{\mathrm{w}}$ of seawater in this area [Dahl and Oppo, 2006]. Nutrient enrichment through upwelling supports high productivity off Arabia, Somalia and southeastern Arabian Sea during this period [Qasim, 1977]. Increased productivity is also observed during the northeast monsoon north of about $15^{\circ} \mathrm{N}$ latitude. The subsurface water renewal in the Indian Ocean mostly occurs through advection of waters from the south and to a smaller extent by outflows from the Persian Gulf and the Red Sea. As the rate of water renewal is moderate and productivity is high, a pronounced and perennial oxygen minimum zone $(\mathrm{OMZ})$ with dissolved $\mathrm{O}_{2}<0.5 \mathrm{ml} \mathrm{I}^{-1}(\sim 22 \mu \mathrm{M})$ has developed in the Arabian Sea at intermediate water depths - between approximately 150 and 1200 m [Wyrtki, 1971; Sen Gupta and Naqvi, 1984]. The Arabian Sea OMZ is one of the largest sites of water column denitrification in the world [Naqvi, 1987]. This process causes an enrichment of ${ }^{15} \mathrm{~N}$ in dissolved nitrate [Brandes et al., 1998] and characteristically elevated $\delta^{15} \mathrm{~N}$ signatures are preserved in sediments. Sedimentary $\delta^{15} \mathrm{~N}$ records have therefore been used to infer changes in denitrification intensity in the past, with high $\delta^{15} \mathrm{~N}$ indicating more vigorous denitrification and probably stronger ISM and vice versa [Altabet et al., 1999, 2002; Ganeshram et al., 2000]. 


\section{Methodology}

For the present study we have used a gravity core AAS62/1 collected during the $62^{\text {nd }}$ cruise of A.A. Sidorenko from southeastern Arabian Sea $\left(11^{\circ} 30.456 \mathrm{~N}, 74^{\circ} 37.388 \mathrm{E}\right)$ at $800 \mathrm{~m}$ water depth (Figure 1). The core length was $5.08 \mathrm{~m}$ and it was sub-sampled at $2 \mathrm{~cm}$ intervals in the upper $100 \mathrm{~cm}$ and at $5 \mathrm{~cm}$ intervals in the rest of the core. As the core was being cut the sediment colour was checked with the rock colour chart and was found to be grayish olive green (5 GY 3/2) uniformly throughout the core.

For measurement of the oxygen isotopic composition of carbonate $\left(\delta^{18} \mathrm{O}_{\mathrm{C}}\right)$, shells of planktonic foraminifer Globigerinoides ruber were selected. G. ruber lives throughout the year in the Arabian Sea, and calcifies above $80 \mathrm{~m}$ depth [Dahl and Oppo, 2006]. These species were handpicked from the coarse fraction (250-350 $\mu \mathrm{m}$ size) using binocular microscope and cleaned ultrasonically. About ten $G$. ruber tests were selected from each of the 125 sediment intervals and analyzed for stable oxygen isotopes on GV Isoprime Mass Spectrometer. All the values are given in \%o relative to PDB. Repetitive analysis of the NBS 18, 19 and internal laboratory standards revealed that analytical standard deviation was better than $\pm 0.07 \%$.

Total inorganic carbon (TIC) was determined using a coulometer. $\mathrm{CaCO}_{3}(\%)$ was calculated by multiplying TIC with factor of 8.333 , the reproducibility was found to be better than $5 \%$. In order to estimate total organic carbon $\left(\mathrm{C}_{\mathrm{org}}\right)$, total carbon was measured by CNS elemental analyser (NCS 2500) and $C_{\text {org }}$ was derived from the difference between total carbon and TIC, with a reproducibility of $\pm 1 \%$.

For the analysis of the land derived (terrigenous) sediment grain size, $3 \mathrm{~g}$ of sediment sample was taken in a beaker. Sea-derived materials like organic matter and $\mathrm{CaCO}_{3}$ were removed by treating with $\mathrm{H}_{2} \mathrm{O}_{2}$ and $1 \mathrm{~N} \mathrm{HCL}$ till no more effervescence was seen. The residue was suspended in distilled water and centrifuged; the process was repeated till all the acid was removed. The sample was then suspended in $30 \mathrm{ml}$ of distilled water. 10 to $12 \mathrm{ml}$ of the well-stirred slurry (depending on the obscuration range of the instrument) was analyzed using Malvern Laser particle size analyser (MasterSizer 2000). The mud fraction of the sediment was divided into different size grades following Wentworth classification [Folk, 1968].

For the analyses of carbon and nitrogen isotopic composition of the sedimentary organic matter, $2 \mathrm{~g}$ of powdered sample was decalcified (treated with $1 \mathrm{~N} \mathrm{HCl}$ for the removal of $\mathrm{CaCO}_{3}$ ). The residue was suspended in distilled water and centrifuged. The process was repeated till all the acid was 
removed and the decalcified sediment was dried in an oven at $60^{\circ} \mathrm{C}$. The decalcified powered samples $(\sim 20 \mathrm{mg})$ were weighed in clean tin cups for analysis. A Delta $\vee$ plus Stable Isotope Ratio Mass Spectrometer $\left(\right.$ Thermo $^{\circledR}$ ) coupled with a Euro-Vector Elemental Analyzer was used for isotopic measurements in a continuous flow mode. The $\delta^{13} \mathrm{C}$ and $\delta^{15} \mathrm{~N}$ values are expressed as per mil (\%o) deviations of the isotopic ratios from the Pee Dee Belemnite (PDB) and air standards, respectively. The analytical standard deviation based on replicate analyses of laboratory standards was about $\pm 0.2 \%$ for $\delta^{15} \mathrm{~N}$ and $\pm \mathrm{O} .3 \%$ for $\delta^{13} \mathrm{C}$.

For $\mathrm{Mg} / \mathrm{Ca}$ analysis 20 shells of $\mathrm{G}$. ruber were selected under a binocular microscope from the $360-440 \mu \mathrm{m}$ size fraction and gently crushed. Above core depth of $175-180 \mathrm{~cm}$, the sensu stricto morphotype was strictly chosen, below this depth few sensu lato morphotype specimens needed to be included in order to have sufficient material for analysis. Cleaning was performed according to the protocol of Barker et al. [2003]. Mg/Ca ratios were measured on an Agilent Technologies 700 Series inductively coupled plasma-optical emission spectrometer (ICP-OES) equipped with an autosampler at the Center for Marine Environmental Sciences, Bremen. Instrumental precision during the analytical session was monitored by analysis of an in-house standard solution with an average $\mathrm{Mg} / \mathrm{Ca}$ of $2.96 \mathrm{mmol} / \mathrm{mol}(\mathrm{n}=20 ; \sigma=0.01 \mathrm{mmol} / \mathrm{mol})$ run after every five samples. For inter-laboratory comparison we measured the $\mathrm{Mg} / \mathrm{Ca}$ of carbonate reference material ECRM 752-1 before and after the samples. Its $\mathrm{Mg} / \mathrm{Ca}$ ratio was on average $3.83 \mathrm{mmol} / \mathrm{mol}(\mathrm{n}=4 ; \sigma=0.01 \mathrm{mmol} / \mathrm{mol})$, in good agreement with the reported $\mathrm{Mg} / \mathrm{Ca}$ ratio of $3.75 \mathrm{mmol} / \mathrm{mol}$ [Greaves et al., 2008]. Analytical precision based on three replicate measurements of each sample was on average $0.11 \%$ for $\mathrm{Mg} / \mathrm{Ca}$.

$\mathrm{Mg} / \mathrm{Ca}$ temperatures were calculated using the calibration of Anand et al. [2003] for G. ruber (white): $\mathrm{Mg} / \mathrm{Ca}=0.48 \exp \left(0.085^{\star} \mathrm{T}\right)$. The $\delta^{18} \mathrm{O}_{\mathrm{C}}$ measured on $\mathrm{G}$. ruber was corrected for continental ice volume using data set of Waelbroeck et al. [2002] to obtain the residual $\delta^{18} \mathrm{O}_{\mathrm{C}}$. Further $\delta^{18} \mathrm{O}_{W}$ was obtained using equation of Bemis et al. [1998]: $\quad \delta^{18} \mathrm{O}_{W}=0.27+\left(\left(\mathrm{T}-16.5+4.8^{*} \delta^{18} \mathrm{C}\right) / 4.8\right)$ where $\mathrm{T}$ is $\mathrm{Mg} / \mathrm{Ca}$ derived SST and $\delta^{18} \mathrm{C}$ is residual $\delta^{18} \mathrm{O}_{\mathrm{C}}$. To obtain salinity from $\delta^{18} \mathrm{O}_{\mathrm{w}}$ we used the equation given by Dahl and Oppo [2006]: $S=\left(\delta^{18} \mathrm{O}_{W}+20\right) / 0.57$.

Chronological control on the core was achieved through 10 AMS ${ }^{14} \mathrm{C}$ dates on $\mathrm{G}$. ruber at Woods Hole Oceanographic Institution (Table 1). The ages were calibrated using Calib 5.0.2 using $\Delta \mathrm{R}$ $138 \pm 64$ years [Stuiver et al., 2005] and an age model was constructed through linear interpolation between the measured ages. The average age between two points was found to be $0.13 \mathrm{ka}$. The topmost age obtained at 6-8 $\mathrm{cm}$ interval was $1.18 \mathrm{ka} \mathrm{BP}$; this was extrapolated to the surface of the core. Based on this extrapolation the core surface $(0-2 \mathrm{~cm})$ dated $0.64 \mathrm{ka}$ BP. The computed 
sedimentation rates between AMS dated tie points were found to vary between 6.3 and $98.7 \mathrm{~cm} / \mathrm{ka}$ (Figure 2A). Higher sedimentation rates are associated with low sea level and decreased as the sea level rose except between 2.8 and $2.3 \mathrm{ka} \mathrm{BP}(85 \mathrm{~cm})$ that could not be explained.

The $\delta^{18} \mathrm{O}_{\mathrm{C}}$ from the present study and published literature has been put together for different time slices in the southeastern Arabian Sea to distinguish influence of Bay of Bengal water in the study area (Figure 2B-E, Table 2). The $\delta^{18} \mathrm{O}_{\mathrm{c}}, \delta^{15} \mathrm{~N}, \mathrm{SST}, \mathrm{SSS}, \delta^{18} \mathrm{O}_{\mathrm{w}}, \mathrm{CaCO}_{3}, \mathrm{C}_{\text {org }}$ and grain size have been plotted against interpolated ages (Figure 3). We have compared our records with the other published data from the eastern Arabian Sea (Figure 4) to understand the timings of major ISM events and to synthesize region-wide paleo-monsoon sequences. We evaluate the link of ISM with changes in insolation and atmospheric $\mathrm{CH}_{4}$ content as recorded in the GISP2 record (Figure 5). For a comparison with the Asian summer monsoon during B-A time, we have used $\delta^{18} \mathrm{O}_{C}$ data from the Hulu and Timta caves plotted along with those from GISP2 (Figure 6).

Frequency analysis of the $\delta^{18} \mathrm{O}_{\mathrm{C}}$ record have been performed using the red-noise spectrum analysis of the program REDFIT which is based on Lomb periodogram and mainly appropriate for unequally spaced time series. The significance levels are presented to test reliability of periodicities as shown by spectral peaks (Schulz and Mudelsee, 2002).

\section{Results}

\section{Variations in $\delta^{18} \mathrm{O}$}

The observed $\delta^{18} \mathrm{O}_{\mathrm{C}}$ values of $\mathrm{G}$. ruber vary between -3.4 and $-0.51 \%$ over the past $16.7 \mathrm{ka}$ (Figure 3). The highest $\delta^{18} \mathrm{O}_{\mathrm{C}}$ values are expectedly observed in the oldest sediment $(-0.6 \%)$ and during the Younger Dryas (YD), whereas lower values characterise B-A event and the Holocene period. The $\mathrm{B}-\mathrm{A}$ event is marked by lower values of $\delta^{18} \mathrm{O}_{\mathrm{C}}$, falling rapidly from $\sim-0.6 \%$ at $15.3 \mathrm{ka} \mathrm{BP}$ to $-1.7 \%$ o at $14.4 \mathrm{ka}$ BP and $\sim-1.5 \%$ at $14 \mathrm{ka}$ BP to $-2.0 \%$ at $13.4 \mathrm{ka}$ BP. The YD around $12.5 \mathrm{ka}$ BP is marked by $\delta^{18} \mathrm{O}_{\mathrm{C}}$ increase to $\sim-1.3 \%$. Thereafter, at the beginning of Holocene there is an abrupt $\delta^{18} \mathrm{O}_{\mathrm{C}}$ decrease by $1.9 \%$ within a short period of 200 years. Within the Holocene (since $10 \mathrm{ka} B P$ ) the $\delta^{18} \mathrm{O}_{\mathrm{C}}$ variations are quite large, ranging between -3.4 and $-2.3 \%$. Comparatively higher values are observed around 7.5 and 4.5 ka BP with uniformly low values ( -3\%o) from 7 to 5.6 ka BP (Figure 3). 
Variations in $\mathrm{C}_{\text {org }}, \delta^{15} \mathrm{~N}$ and $\delta^{13} \mathrm{C}$

The $\mathrm{C}_{\text {org }}$ content ranges between 0.6 and $5 \%$, being lower at the beginning of the Holocene and increasing steadily thereafter towards the late Holocene (Figure 3). The $\delta^{15} \mathrm{~N}$ of organic matter ranges between 3.9 and $6.6 \%$ with lower values at $\sim 16$ ka BP and decreasing values during YD. The $\delta^{15} \mathrm{~N}$ and $\delta^{18} \mathrm{O}_{\mathrm{C}}$ follow similar trend during the B-A event with slightly elevated $\mathrm{C}_{\text {org }}$ content (Figure 3 ). The $\delta^{15} \mathrm{~N}$ values rose from $4 \%$ at $11.6 \mathrm{ka} \mathrm{BP}$, just before the beginning of the Holocene to $\sim 6.4 \%$ at the core top. The $\delta^{13} \mathrm{C}$ of organic matter ranges between -22 and $-19 \%$ indicating that the organic matter is dominantly marine.

\section{Sea Surface Temperature (SST), Oxygen isotope ratios of surface waters $\left(\delta^{18} O_{w}\right)$ and Sea Surface Salinity (SSS)}

The core depth of AAS62/1 is well above lysocline and carbonate compensation depth [Naqvi and Naik, 1983], and $\mathrm{Mg} / \mathrm{Ca}$ derived SST at the core top is $28.60^{\circ} \mathrm{C}$ that matches well with the modern SST of $28.58^{\circ} \mathrm{C}$ (Annual average 1960 to 2012, ICOADS data provided by the NOAA/OAR/ESRL PSD, Boulder, Colorado, USA, from their Web site at http://www.esrl.noaa.gov/psd/ ) that rules out the bias due to dissolution. We are also aware about the limitation in SSS estimation [Rohling, 2000; Steinke et al., 2006] and therefore used combination of SST, $\delta^{18} \mathrm{O}_{\mathrm{W}}$, SSS, with other proxies shown in Figure 3 for the interpretation of results.

SST based on $\mathrm{Mg} / \mathrm{Ca}$ ratio ranges between 25 and $30.5^{\circ} \mathrm{C}$, and in general shows an increasing trend from 16.7 ka BP to the core top (Figure 3). The average temperature change for the deglacial and Holocene boundary is $\sim 2.6^{\circ} \mathrm{C}$ Between 16.7 and 15.4 ka BP the average SST was low, $\sim 26.1^{\circ} \mathrm{C}$, whereas during the B-A event there occurred an increase in SST ranging between 26.3 and $28^{\circ} \mathrm{C}$ (average $26.8^{\circ} \mathrm{C}$ ). The YD exhibits a lower temperature $\left(26.1\right.$ to $26.7^{\circ} \mathrm{C}$ ) except for one point at $12.2 \mathrm{ka}$ $\mathrm{BP}$ showing $\sim 28^{\circ} \mathrm{C}$. From the $\mathrm{YD}$ to Holocene boundary there occurred a temperature change of $\sim 2^{\circ} \mathrm{C}$ within a period of $1 \mathrm{ka}$. From 11.9 to $9 \mathrm{ka} \mathrm{BP}$ average SST was $\sim 27.9^{\circ} \mathrm{C}$, and from 9 to $0.6 \mathrm{ka} \mathrm{BP}$ temperature increased to an average value of $28.2^{\circ} \mathrm{C}$.

The $\delta^{18} \mathrm{O}_{\mathrm{W}}$ ranges between -1.2 and $0.9 \%$ (Figure 3). Higher values are observed during 1615.5, YD, 9.3, 7, $4.5 \mathrm{ka}$ BP, whereas lower values are clearly exhibited during the B-A event and most of the Holocene. Extreme pulses of low values are seen at the beginning of Holocene reaching up to 1.5\%. The SSS at core location varies between 32.9 and 36.7. Higher salinity values are observed during 16.2 to $15.2 \mathrm{ka} \mathrm{BP,} \mathrm{YD} \mathrm{and} \mathrm{4.5} \mathrm{ka} \mathrm{BP} \mathrm{(Figure} \mathrm{3).} \mathrm{Lower} \mathrm{salinities} \mathrm{were} \mathrm{associated} \mathrm{with} \mathrm{B-A}$ event and most of the Holocene (Avg. 34.8), and during abrupt ISM event (AE). 


\section{Calcium carbonate content and Grain size}

The $\mathrm{CaCO}_{3}$ content in the core ranges between $23 \%$ and $46 \%$ (Figure 3). Relatively moderate increase in $\mathrm{CaCO}_{3}$ content is observed during $\mathrm{B}-\mathrm{A}$ event associated with slightly increased $\mathrm{C}_{\text {org }}$ (Figure 3). Clay $(<4 \mu \mathrm{m})$, very fine silt $(4$ to $8 \mu \mathrm{m})$, and fine silt ( 8 to $16 \mu \mathrm{m})$ together, and medium silt (16 to 31 $\mu \mathrm{m})$ and coarse silt $(31$ to $64 \mu \mathrm{m}$ ) together follow similar patterns (Figure 3 ). Grain size fractions $<4$ to $31 \mu \mathrm{m}$ and 31 to $64 \mu \mathrm{m}$ show inverse relationships. These medium and coarse silts contents reach the highest values between 9 and $7 \mathrm{ka} \mathrm{BP}$, whereas clay and finer silt dominate during the $\mathrm{YD}, \sim 6.6 \mathrm{ka}$ BP and 3.5-2 ka BP periods (Figure 3).

\section{Discussion}

The sea surface salinity (SSS) and $\delta^{18} \mathrm{O}_{W}$ are known to be lower near the southwest margin of India than offshore in the Arabian Sea as a result of heavy rainfall and land runoff during the ISM (Figure 1) [Dahl and Oppo, 2006; Govil and Naidu, 2010]. Moreover, the Southeastern Arabian Sea also receives inflow of low-salinity surface water from the southeast (Bay of Bengal water) during the northeast monsoon. In the eastern Arabian Sea SSS during the northeast monsoon is low in the south and increases towards north as this low salinity water mixes with the high salinity water of the Arabian Sea. The G. ruber may incorporate $\delta^{18} \mathrm{O}_{\mathrm{C}}$ signature of the ISM and/or the northeast monsoon. Supporting the $\delta^{18} \mathrm{O}_{\mathrm{C}}$ signatures from the intensified northeast monsoon, Tiwari et al. [2005] based on a sediment core study suggested an intensified northeast monsoon that could have led to a more intense flow of low-salinity water from south with low $\delta^{18} \mathrm{O}_{\mathrm{C}}$ into the eastern Arabian Sea during the glacial times. Should this have been the case for the Holocene sediments, the $\delta^{18} \mathrm{O}_{\mathrm{c}}$ values at our core location were expected to be similar or higher than those from the southern core SK-20-185 analyzed by Tiwari et al. [2005] and other cores in this vicinity (Figure 2B-E] as salinity gradient increases from south to north. We have also put together $\delta^{18} \mathrm{O}_{\mathrm{C}}$ of $\mathrm{G}$. ruber from the available literature to look for influence of the Bay of Bengal water into the Arabian Sea at different time slices (Figure 2B-E). The $\delta^{18} \mathrm{O}_{\mathrm{C}}$ values of these three slices at the present study location are much lower than the southern cores suggesting that the core site recording more influence of the ISM. Core SK157-4 studied by Saraswat et al., [2012] located south of the study area (Figure 2B), were Bay of Bengal water passes through equatorial region $\left(2^{\circ} 40^{\prime} \mathrm{N}, 78^{\circ} 00^{\prime} \mathrm{E}\right)$ before reaching the Arabian Sea yielded core top $\delta^{18} \mathrm{O}_{\mathrm{W}}$ of $0.3 \%$ (with SSS 34.7) that is much higher than our core top $\delta^{18} \mathrm{O}_{\mathrm{W}}$ of $-0.5 \%$ (with SSS 34.7), suggesting that the present core must have incorporated more signatures of precipitation/runoff during ISM. The core AAS62/1 located in the southeastern Arabian Sea is closer to the Indian continental margin (Figure 2B) where there is precipitation and freshwater influx during the ISM (Figure 1A-F) that must have been 
incorporated in the $\delta^{18} \mathrm{O}_{\mathrm{C}}$. Therefore, G. ruber from this region that lives throughout the year and calcifies above $80 \mathrm{~m}$ depth [Dahl and Oppo, 2006] is expected to record $\delta^{18} \mathrm{O}_{\mathrm{c}}, \delta^{18} \mathrm{O}_{\mathrm{w}}$ and SSS more signatures of ISM rainfall and runoff. The stable isotope and land-derived (sediment texture) records of AAS62/1 reveal well-resolved environmental variations during the last deglaciation and Holocene. Given the proximity of the core location to the region of highest rainfall along the Indian west coast (Figure 1), the planktonic $\delta^{18} \mathrm{O}_{\mathrm{c}}$ and $\delta^{18} \mathrm{O}_{\mathrm{w}}$ probably serve as proxy of precipitation and runoff (Figure 3).

The core AAS62/1 includes a short period of $\sim 1.5 \mathrm{ka}$ (bottom $80 \mathrm{~cm}$ ) before the B-A event. The time series records of $\delta^{18} \mathrm{O}_{\mathrm{C}}, \mathrm{Mg} / \mathrm{Ca}$ derived SST, $\delta^{18} \mathrm{O}_{\mathrm{w}}, \delta^{15} \mathrm{~N}$ and sediment texture during this period exhibit short-term oscillation in the water column characteristics and terrigenous influx. The $\mathrm{C}_{\text {org }}$ (1.3 to $2.1 \%$ ) and $\mathrm{CaCO}_{3}$ contents ( 28 to $\left.34 \%\right)$ during this period show minor variations. Between 16.7 and $15.1 \mathrm{ka} \mathrm{BP}$ the $\delta^{18} \mathrm{O}_{\mathrm{C}}$ values exhibit fluctuations (with increases up to $0.4 \%$ ) with periodicity of 0.15 to $0.3 \mathrm{ka}$. This period is marked with increases in $\delta^{18} \mathrm{O}_{\mathrm{w}}$ by $0.5 \%$ and SSS by 0.6 (Figure 3). As the study area at the present time is marked with higher freshwater inflow during the ISM (Figure 1), the increases in $\delta^{18} \mathrm{O}_{\mathrm{W}}$ and SSS during 16.7 to $15.1 \mathrm{ka} \mathrm{BP}$ suggest that there must have been reduced freshwater inflow to this region due to weaker ISM. Furthermore from $16.8 \mathrm{ka}$ to $16 \mathrm{ka} \delta^{15} \mathrm{~N}$ decreased by $\sim 1 \%$ (Figure 3 ) suggesting reduction in the denitrification intensity. The decrease in denitrification in the past has been related to reduced ISM induced upwelling and a consequent decrease in water column productivity, leading to lower oxygen demand at depth [Altabet et al., 1999]. The ISM induced denitrification $\left(\delta^{15} \mathrm{~N}\right)$ signatures have also been recorded in the eastern Arabian Sea [Ganeshram et al., 2000; Agnihotri et al., 2008; Banaker et al., 2005; Kessarkar et al., 2010]. The decrease in denitrification observed in the present study may also be similarly attributed to a less intense ISM. To check, if this signature of weaker ISM has also been archived in other cores of the eastern Arabian Sea we have put together $\delta^{18} \mathrm{O}_{\mathrm{C}}$ data from the present study with other published records (Figure 4). It appears that major variations in the $\delta^{18} \mathrm{O}_{\mathrm{C}}$ did not occur during this period in the eastern Arabian Sea. Higher $\delta^{18} \mathrm{O}_{\mathrm{C}}$ values in the core SK 17 (Figures 1 and 4) during this time have been related to weak ISM and associated reduced runoff from the land [Anand et al., 2008]. Weaker ISM during similar period has been inferred from the wind proxy [Sirocko et al., 1993; 1996] and reduced denitrification rates in the northern Arabian Sea have been related to midwater ventilation by advection of more oxygenated Antarctic Intermediate Water during Heinrich events [Suthhof et al., 2001].

Studies on the western Arabian Sea based on geochemical and multi-tracer approach suggest that the ISM intensified in three succession events with first one at 16 ka BP [Sirocko et al., 2000], whereas study in the eastern Arabian sea (off Goa) based on Mg/Ca ration suggest intensification of 
ISM 17 ka BP [Anand et al., 2008]. A recent study by Naidu and Govil [2010] suggests warming in the northern Indian Ocean around 19 ka which is synchronous with deglacial warming in Antarctica. As the warming occurred, the ISM was also intensifying. Our results suggest that the increase in ISM intensity was slow with minor fluctuations till 15.2 ka BP. Thamban et al. [2001], have reported fluctuations in $\delta^{18} \mathrm{O}_{\mathrm{C}}$ values around $15.2 \mathrm{ka} \mathrm{BP}$ that were attributed to increase in precipitation and warming of sea surface. Further the composite oxygen isotope section of cores AAS62/1 and AAS62/2 and other results from the Southeast Arabian Sea (Figure 4) suggest major intensification of ISM could have started after the LGM around $15.2 \mathrm{ka}$ BP. This is consistent with the results of Naqvi and Fairbanks [1996] who reported a cessation of deep water outflow from the Red Sea presumably in response to a major intensification of the southwest monsoon around 15.5 ka B.P.

The B-A event is prominently seen in the proxy records with lower $\delta^{18} \mathrm{O}_{\mathrm{C}}, \delta^{18} \mathrm{O}_{\mathrm{W}}$ and SSS, and an increase in coarser grained terrigenous sediments. From 15.2 to $13.4 \mathrm{ka}$ BP there is stepwise decline in $\delta^{18} \mathrm{O}_{\mathrm{c}}$ by $\sim 1.4 \%$, $\delta^{18} \mathrm{O}_{\mathrm{W}}$ by $0.98 \%$ and SSS by 2.08 . The declining $\delta^{18} \mathrm{O}_{\mathrm{c}}, \delta^{18} \mathrm{O}_{\mathrm{W}}$ and SSS clearly suggest increase in precipitation/runoff, as the study area is in the vicinity of high precipitation and runoff (Figure $1 \mathrm{~A}-\mathrm{F}$ ). The lower values of $\delta^{18} \mathrm{O}_{\mathrm{C}}$ are very well correlated with increase in coarser grain size fraction (medium to coarse silt), supporting increase in land runoff hence increased terrigenous material. The $\delta^{18} \mathrm{O}_{\mathrm{w}}$ and SSS are similar to the present (surface sediments). Another core, AAS62/2, located in the area but away from the margin, also shows an increase in $\delta^{18} \mathrm{O}_{\mathrm{C}}$ by $1 \%$ o during this period (Figure 4). The fluctuations in $\delta^{18} \mathrm{O}_{\mathrm{C}}$ are not well resolved in core AAS62/2 during this period (Figure 4), which could be due to low sedimentation rate. The $\mathrm{C}_{\text {org }}(1-2 \%)$ and $\mathrm{CaCO}_{3}(24-31 \%)$ show slightly elevated values during this period. The $\delta^{15} \mathrm{~N}$ shows stepwise increases by $\sim 2.4 \%$ from 16 ka to 13.4 ka suggesting increase in denitrification rate. This period is known to be the period of a more intensified monsoon. A stronger monsoon is expected to have been associated with higher productivity, in turn sustaining elevated mid-depth denitrification, similar to the present (surface sediments). The intensity of the summer monsoon seems to have been increased at the advent of B-A event. Increase in the ISM strength during 15.3 to 14.7 ka BP has been reported by Overpeck et al. [1996] who related it to the warming of the Tibetan Plateau and associated strengthening of the pressure gradient needed for a strong monsoon.

The $\delta^{18} \mathrm{O}_{\mathrm{C}}$ reaches the lowest values $\sim 2.0 \%$ at about $13.4 \mathrm{ka}$ BP (Figure 3) and starts increasing stepwise to $1.3 \%$ at $12 \mathrm{ka}$ BP. Similarly there is increase in $\delta^{18} \mathrm{O}_{\mathrm{w}}$ by $0.88 \%$ and SSS by 1.55 , suggesting decrease in freshwater influx (precipitation/runoff) into the study area. This indicates that there was an abrupt decrease in ISM intensity that coincided with the onset of the YD. This 
increase in $\delta^{18} \mathrm{O}_{\mathrm{C}}$ is also associated with decrease in $\delta^{15} \mathrm{~N}$ suggesting suppressed denitrification during the YD.

The ISM system acquires energy from the subtropical Indian Ocean whereas the East Asian system does so from the western Pacific Warm Pool [Wang et al., 2005]. The Indian monsoon is often considered to be part of the Asian monsoon. A compilation of the Holocene paleo-studies by Staubwasser and Weiss [2006] revealed that the South Asian monsoon prevailed in the Himalayas and the equatorial Indian Ocean and not in the Indian Peninsula. These authors suggested that the south Asian summer monsoon rain was not uniformly enhanced during the early and mid Holocene. The B-A event has been well documented in marine cores from the northern [e.g. Altabet et al., 2002] and western [e.g. Ivanochko et al., 2005] Arabian Sea. Whereas very few cores from the southeastern Arabia Sea have preserved the B-A event signatures [Rao et al., 2010; Tiwari et al., 2005; Singh et al., 2006] with relatively low resolution. The present data set with moderately high sedimentation rate (53$99 \mathrm{~cm} / \mathrm{kyr}$ ) during the B-A event provides evidence for increase in the ISM. A comparison of $\delta^{18} \mathrm{O}_{\mathrm{C}}$ data from AAS62/1 is shown with very high resolution data from the Timta cave, Hulu cave, and GISP2 (Figure 6). The moisture to the AAS62/1 site is derived from the Arabian Sea, to Timta caves from the Bay of Bengal and Hulu caves from the Pacific Ocean. These three regions are connected by the ITCZ; the movement of the position of the ITCZ may have resulted in changes in monsoonal precipitation. Previous studies by Sinha et al. [2005] in the Himalayan region suggested coupling between the Asian monsoon and the climate of the North Atlantic. Present core under study may have effected by changes in sedimentation rates and dating error; higher resolution core from this area would bring out better picture of the relation between these three regions.

The increased ISM strength during the B-A event seems to have been interrupted by a short period of Younger Dryas, which is marked by high $\delta^{18} \mathrm{O}_{\mathrm{C}}, \delta^{18} \mathrm{O}_{\mathrm{W}}$, SSS and low SST, indicating reduced precipitation/runoff to the study area. The $\delta^{15} \mathrm{~N}$ values also decreased during this time suggesting less intense denitrification compared to the B-A period. Reduced denitrification during this time might be the result of more oxygenated intermediate waters due to advection of Antarctic intermediate waters during YD [Suthhof et al., 2001; Pichevin et al., 2007]. Further, reduced coarser grain-size (medium and coarse silt) suggests lower input from the land, which could also be linked to weaker ISM.

The record shows three abrupt shifts in $\delta^{18} \mathrm{O}_{c}$ to very low values toward the end of the Younger Dryas. Low $\delta^{18} \mathrm{O}_{\mathrm{C}}$ values observed here could be the result of diagenetic alteration in G. ruber. We, however, did not observe any visible evidence of recrystalization or dissolution on $G$. ruber and the samples were well preserved with abundant pteropods. Planktonic foraminiferal population variability 
could also give lower values. As we have chosen monospecific species of G. ruber of specific size range and about 10 specimens were taken per run to get the average values there are reduced chances of error. These low values for example, from 12 to $11.8 \mathrm{ka} B P$ the $\delta^{18} \mathrm{O}_{\mathrm{C}}$ fell from $-1.34 \%$ to $3.29 \%$. A shift by $-1.9 \%$ within a period of $\sim 200$ years could be caused largely by lower salinity arising from greater rainfall/land runoff that has been reflected in reduced $\delta^{18} \mathrm{O}_{\mathrm{W}}$ and SSS. Three such pulses of massive freshwater inputs are recorded in our core, centred around 11.7, 11.6 and 11.2 ka BP, suggesting high variability of monsoonal rainfall during this period (see AE Figure 3) . A similar shift in $\delta^{18} \mathrm{O}_{\mathrm{C}}$ is also observed (as a single peak, perhaps due to poorer resolution) in the nearby core AAS62/2 (Figure 4). If we compare these data with the atmospheric methane content record from GISP2 (Figure 5), a high methane concentration seems to be associated with the intensified ISM. However, during this time denitrification rate appears to have been at its lowest that needs explanation. During increased ISM intensity, high precipitation/runoff in the study area may have resulted in stratification due to water column salinity gradient. During ISM there exist under current with more oxygenated water moving north in the study area. At the times of intensified ISM this current must have been stronger and may be keeping the subsurface water oxygenated and hence reducing denitrification [Kessarkar et al. 2010.]. Increase in the monsoon strength during 11.5-10.8 ka BP has been reported by Overpeck [1996], and more humid conditions around $11 \mathrm{ka} \mathrm{BP}$ have been recorded by Cancer et al. [2005] in the Nilgiris (western Peninsular India). Based on the sediment core from the Andaman Sea Naqvi et al. [1994] have reported shift in $\delta^{18} \mathrm{O}_{\mathrm{C}}$ and $\delta^{13} \mathrm{C}$ of benthic foraminifera after the YD and related to the monsoonal changes. Similar oscillations at the end of the YD have also been reported from another core in the Andaman Sea and related to increase in the Irrawaddy River runoff and Indian Ocean Monsoon [Rashid et al., 2007]. Based on an evaluation of the published data Morrill et al. [2003] concluded that toward the end of the Pleistocene ( 11.5 ka BP) Asian monsoon precipitation increased dramatically supporting a link between the North Atlantic climate and Asian monsoon [Wang and Fan, 1987; Overpeck, 1996]. Warming and an increase in Asian monsoon intensity at about the same time are also indicated by the $\delta^{18} \mathrm{O}_{\mathrm{C}}$ record from the South China Sea [Steinke et al., 2006]. Further, an increase in deepwater formation occurred around this period (within the limits of radiocarbon dating) in the North Atlantic suggesting atmospheric teleconnections between the two regions. Studies on stalagmites from the Oman point to monsoon maximum during the early Holocene [Neff et al; 2001; Fleitmann et al., 2003]. Comparing our oxygen isotope data with the $30^{\circ} \mathrm{N}$ insolation and methane data from GISP2, it would appear that intensification of Asian monsoon and enhanced methane production occurred in response to insolation maximum in the northern hemisphere. The YD interrupted this trend, however, and when the YD perturbation faded there was an abrupt intensification of the monsoons that peaked with the insolation maximum at $30^{\circ} \mathrm{N}$ (Figure 5). Superimposed on the insolation-forced increase in the 
monsoon, there have been short term changes as evident from the abrupt freshwater discharge events recorded by us toward the end of the YD. Examination of such decadal to centennial scale changes and understanding of their causes require high sedimentation records during key time slices [e.g. Gupta et al., 2003; Kurian et al., 2009].

Presence of lower $\delta^{18} \mathrm{O}_{\mathrm{C}}$ suggests warmer and lower salinity conditions after $11 \mathrm{ka}$ BP. The decrease in $\delta^{18} \mathrm{O}_{\mathrm{C}}$ between 11 and $10 \mathrm{ka}$ BP along with the presence of higher coarser grain size during this time suggest increase in land derived material. The $\delta^{18} \mathrm{O}_{\mathrm{C}}$ has fluctuated by $< \pm 0.5 \%$ (Figure 3) since 10.5 ka B.P.; by contrast, the $\delta^{15} \mathrm{~N}$ values increased steadily up to $\sim 3$ ka B.P. suggesting intensification of denitrification through most of the Holocene following a minor minimum that occurred shortly after 10 ka B.P. Similar increase in $\delta^{15} \mathrm{~N}$ has been reported by Pichevin et al., [2007] and suggests that northeastern Arabian Sea influence Holocene climate. The $\mathrm{C}_{\text {org }}$ and $\mathrm{CaCO}_{3}$ content also follow the increasing trend, like that of $\delta^{15} \mathrm{~N}$ and do not follow the insolation changes. Increase in ISM has been discussed by Tiwari et al. [2010] during late Holocene that does not follow insolation and suggest that the internal feedback processes to be equally important. The intensification of ISM has been reported to occur in two steps i.e. 9.4 and $9.1 \mathrm{ka}$ BP based on data from the Arabian Sea [Gupta et al., 2003]. Analysis of a core off India at $17^{\circ} 45^{\prime} \mathrm{N}$ suggested that the main event occurred between 9.1 and 8.5 ka BP [Thamban et al., 2001]. The present data set derived from a region that comes under the direct influence of the southwest monsoon does not indicate very large changes, but between 9.1-8 ka BP $\delta^{18} \mathrm{O}_{\mathrm{C}}$ did decrease by $0.4 \%$, associated with relatively invariable $\delta^{18} \mathrm{O}_{\mathrm{W}}$ and SSS. This was also accompanied by an increase in the amount of medium and coarser silt. Other workers [Neff et al., 2001; Gupta et al., 2003] reported abrupt changes in summer monsoon frequently occurring during the Holocene.

Between 7 and $5.6 \mathrm{ka} \mathrm{BP} \delta^{18} \mathrm{O}_{\mathrm{C}}$ values are nearly constant $(\sim-3 \%$, with very small variation in $\delta^{18} \mathrm{O}_{\mathrm{C}}$ and SSS suggesting stable ISM, that is in agreement with other records from this region (Figure 4). The period from 7.2 to $6.5 \mathrm{ka}$ BP is regarded as having being optimal for vegetation growth based on the pollen record, corresponding to the second humid phase [Van Campo et al., 1996]. Reduction in the input of the coarser fraction at this time can be explained by local changes in the sea level that was close to or above the present mean sea level [Mathur et al., 2004]. The increase in the $\delta^{18} \mathrm{O}_{\mathrm{C}}, \delta^{18} \mathrm{O}_{\mathrm{W}}$, SSS and decrease in SST $\sim 5.5 \mathrm{ka}$ BP suggests weakening of ISM with the minimum centred at $4.5 \mathrm{ka} \mathrm{BP}$. This is the period of reduction in freshwater flux by the Indus River [Staubwasser et al., 2003]. After $4.5 \mathrm{ka} \mathrm{BP}$ the lower $\delta^{18} \mathrm{O}_{\mathrm{C}}, \delta^{18} \mathrm{O}_{\mathrm{W}}$ and SSS suggest the end of the dry period with intensification of ISM with a peak at about $3 \mathrm{ka} \mathrm{BP}$. Observation of higher $\delta^{18} \mathrm{O}_{\mathrm{C}}, \delta^{18} \mathrm{O}_{\mathrm{W}}$ and SSS at 2.5 
to 2.3 ka BP suggests a dry phase. This is also evident from other records from the Southwest Indian margin [Thamban et al., 2007]. Reduced precipitation during this period is consistent with data from Dongge cave in South China (Wang et al., 2005).

Spectral analysis of oxygen isotope data $\delta^{18} \mathrm{O}_{\mathrm{C}}$ was carried out to look for any cyclicity in the paleo monsoon strength and understand controlling factors using the Redfit program [Schulz and Mudelsee, 2002]. The $\delta^{18} \mathrm{O}$ of $G$ ruber exhibits periodicities of 390, 500 and 620 years above the $95 \%$ confidence level (Figure 7). The 500 year periodicity has also been reported by Bhushan et al. [2001] and attributed to the modulation of monsoon by the Atlantic deep water formation. Periodicity of 512 yrs has been reported by Wang et al. [2005]. Considering the ITCZ connection of the Indian monsoon with the East Asian monsoon, this periodicity of 500 could be related to the position of the ITCZ.

\section{Conclusions}

Post-glacial intensification of ISM with intensification of subsurface denitrification appears to have begun at about $15.2 \mathrm{ka}$ BP coinciding with the onset of the B-A event. The ISM intensification was coupled with strengthening of the Asian summer monsoon and warming in the North Atlantic. The trend of intensifying monsoons, probably forced by the increase in northern hemisphere summer insolation, was however interrupted by the YD cooling that also led to a decrease in denitrification intensity. As the influence of the YD perturbation faded, a rapid intensification of ISM occurred with three very wet events of short duration occurring between 11.8 and 11.2 ka BP. Changes in ISM also occurred during the Holocene with relatively arid conditions prevailing around $4.5 \mathrm{ka} \mathrm{BP}$, and humid conditions centred around $3 \mathrm{ka} \mathrm{BP}$. The ISM was relatively stable between $\sim 7$ and 5.6 ka BP. Subsurface denitrification, in general, appears to have undergone an increase through the Holocene. The observed periodicity of 500 years is comparable to that of North Atlantic deep water formation and the East Asian monsoon.

Acknowledgements: We thank Director, National Institute of Oceanography, Goa, for the facilities and encouragement. We thank Tim Haarmann, MARUM- Zentrum für Marine Umweltwissenschaften / Universität Bremen for Mg/Ca analysis. Drs. P. Babu and V. Ramaswamy are thanked for $\mathrm{CN}$ and LPSA analysis. Dr. Ashish Sinha, California State University, USA is thanked for providing Timta cave data. This work is supported by ISRO-GBP program and Young Scientist Project, Department of Science and Technology, New Delhi. This is NIO contribution No 


\section{References}

Agnihotri, R., S. Kurian, M. Fernandes, K. Reshma, W. DeSouza, S. W. A. Naqvi (2008), Variability of subsurface denitrification and surface productivity in the coastal eastern Arabian Sea over the past seven centuries, Holocene, 18, 755-764.

Altabet, M. A., D. W. Murray, W. L. Prell (1999), Climatically linked oscillations in Arabian Sea denitrification over the past 1 m.y.: Implications for the marine $\mathrm{N}$ cycle, Paleoceanography, 4, 732-743

Altabet, M. A., M. J. Higginson, and D.W. Murray, (2002), The effect of millennial-scale changes in Arabian Sea denitrification on atmospheric $\mathrm{CO}_{2}$. Nature, 415, 159-162.

Anand, P., H. Elderfield, and M. H. Conte (2003), Calibration of Mg/Ca thermometry in planktonic foraminifera from a sediment trap time series, Paleoceanography, 18(2), 1050, doi:10.1029/2002PA000846.

Anand, P., D. Kroon, A. D. Singh, R. S. Ganeshram and G. Ganssen (2008), Coupled sea surface temperatureseawater $\delta^{18} \mathrm{O}$ reconstructions in the Arabian Sea at the millennial scale for the last $35 \mathrm{ka}$, Paleoceanography, 23, PA4207, doi:10.1029/2007PA001564.

Banakar, V. K., B. S. Mahesh, G. Burr, A. R. Chodankar (2010), Climatology of the Eastern Arabian Sea during the last glacial cycle reconstructed from paired measurement of foraminiferal $\delta^{18} \mathrm{O}$ and $\mathrm{Mg} / \mathrm{Ca}$, Quat. Res., 73, 535-540.

Banakar, V.K., T. Oba, A.R. Chodankar, T. Kuramoto, M. Yamamoto and M. Minagawa (2005), Monsoon related changes in sea surface productivity and water column denitrification in the Eastern Arabian Sea during the last glacial cycle, Mar. Geol., 219, 99-108.

Barker , S., M. Greaves and H. Elderfield, (2003), A study of cleaning procedures used for foraminiferal Mg/Ca paleothermometry, Geochem. Geophys. Geosyst., 4

Bemis, B. E., H. J. Spero, J. Bijma, and D. W. Lea (1998), Reevaluation of the oxygen isotopic composition of planktonic foraminifera: Experimental results and revised paleotemperature equations, Paleoceanography, 13(2), 150-160, doi:10.1029/98PA00070.

Bhushan, R., K. Dutta and B. L. K. Somayajulu (2001), Concentrations and burial fluxes of organic and inorganic carbon on the eastern margins of the Arabian Sea. Mar. Geol., 178, 95-113.

Brandes, J. A., A. H. Devol, T. Yoshinari, D. A. Jayakumar, S. W. A. Naqvi, (1998), Isotopic composition of nitrate in the central Arabian Sea and eastern tropical North Pacific: A tracer for mixing and nitrogen cycles, Limnol. Oceanogr., 43, 1680-1689.

Cancer, L., D. L. Seen, Y. Gunnell, B. R. Ramesh and G. Bourgeon (2007), Spatial heterogeneity of land cover response to climatic change in the Nilgiri highlands (Southern India) since the last glacial maximum, The Holocene, 17, 195-205, doi: 10.1177/0959683607075833.

Clark, O.C., J. E. Cole and P. J. Webster (2000), Indian Ocean SST and Indian summer monsoon rainfall: predictive relationships and their decadal variability, J. Clim., 14, 2503-2519

Clemens S., P. Wang and W. Prell, (2003), Monsoons and global linkage on Milankovitch and sub-Milankovitch time scales, Mar. Geol., 201, 1-3.

Clement, A. C., R. Seager and M. A. Cane (1999), Oribital controls on ENSO and tropical climate, Paleoceanography, 14,441-456. 
Dahl, K. A., and D. W. Oppo (2006), Sea surface temperature pattern reconstructions in the Arabian Sea, Paleoceanography, 21, PA1014, doi:10.1029/2005PA001162.

Fennig K., A. Andersson, S. Bakan, C. Klepp, M. Schroeder, (2012), Hamburg Ocean Atmosphere Parameters and Fluxes from Satellite Data - HOAPS 3.2 - Monthly Means / 6-Hourly Composites. Satellite Application Facility on Climate Monitoring. doi:10.5676/EUM_SAF_CM/HOAPS/V001.

Fleitman, D., S. J. Burns, M. Mudelsee, U. Neff, J. Kramers, A. Mangini, A. Matter (2003), Holocene forcing of the Indian monsoon recorded in a stalagmite from Southern Oman, Science, 300, 1737-1739.

Fleitman, D., S. J. Burns, A. Mangini, M. Mudelsee, J. Kramers, I. Villa, U. Neff, A. A. Al-Subbary, A. Buettner, D., Hippler, A. Matter (2007), Holocene ITCZ and Indian monsoon dynamics recorded in stalagmites from Oman Yemen (Socotra), Quatern. Sci. Rev., 26, 170-188.

Folk, R. L. (1968), Petrology of the sedimentary rocks, Hemphills, Drawer's M., University Station, Austin, Texas $170 \mathrm{pp}$.

Ganeshram, R. S., T. F. Pedersen, S. E. Calvert, G. W. McNeill and M. R. Fontugne (2000), Glacial-intergalcial variability in denitrification in the world's oceans: Causes and consequences, Paleoceanography, 14, 361376.

Govil, P. and P. D. Naidu (2010), Evaporation-precipitation changes in the eastern Arabian Sea for the last 68 ka: Implications on monsoon variability, Paleoceanography, 25, PA1210, doi:10.1029/2008PA001687.

Greaves, M., et al. (2008), Interlaboratory comparison study of calibration standards for foraminiferal Mg/Ca thermometry, Geochem. Geophys. Geosyst., 9, Q08010, doi:10.1029/2008GC001974.

Gupta, A. K., D. M. Anderson, and J. T. Overpeck (2003), Abrupt changes in the Asian southwest monsoon during the Holocene and their links to the North Atlantic Ocean, Nature, 421, 354- 356, doi:10.1038/nature01340.

Ivanochko T. S., R. S. Ganeshram, G.-J. A. Brumer, G. Ganssen, S. J. A. Jung, S. G. Morton, and D. Kroon (2005), Variations in tropical convection as an amplifier of global climate change at millennial scale, Earth Planet. Sci. Lett., 235, 302-314, doi:10.1016/j.epsl.2005.04.002.

Jung, S. J. A., G. Davies, G. Ganssen and D. Kroon (2004), Stepwise Holocene aridification in NE-Africa deduced from dust borne radiogenic isotope records, Earth Planet. Sci. Lett., 221, 27-37.

Kessarkar, P. M. and V. P. Rao (2007), Organic carbon in sediments of the southwestern margin of India: Influence of productivity and monsoon variability during the Late Quaternary, J. Geol. Soc. India, 69, 4252.

Kessarkar, P. M.; V. P. Rao, S. W. A. Naqvi, A. R. Chivas and T.Saino (2010), Fluctuations in productivity and denitrification in the southeastern Arabian Sea during the Late Quaternary, Curr. Sci., 99, 485-491.

Kumar. A. A., V. P. Rao, S. K. Patil, P.M. Kessarkar and M. Thamban (2005), Rock magnetic records of the sediments of the eastern Arabian Sea: Evidence for the late Quaternary climatic change, Mar. Geol., 220, 59-82.

Kurian, S., R. Agnihotri,; D. V. Borole, S. W. A. Naqvi, A. M. Ferreira, C. Vale, (2009), Possible solar control on primary production along the Indian west coast on decadal to centennial timescale, J. Quat. Sci., 24, 109116.

Mahesh, B., V.K. Banakar and G. Burr (2011) Paired measurements of foraminiferal $\delta^{18} \mathrm{O}$ and $\mathrm{Mg} / \mathrm{Ca}$ ratios of Indian monsoons reconstructed from Holocene to Last Glacial record, Acta Geol. Sinica, 85, 950-956. 
Mathur, U. B., D. K. Pandey and T. Bahadur (2004), Falling Late Holocene sea level along Indian coast, Curr. Sci., 87, 439-440.

Morrill, C., J. T. Overpeck and J. E. Cole (2003), A synthesis of abrupt changes in the Asian summer monsoon since the last deglaciation, The Holocene, 13, 465-476.

Naidu, P. D. And P. Govil (2010), New evidence on the sequence of deglacial warming in the tropical Indian Ocean, J. Quat. Sci. 25(7), 1138-1143.

Naqvi, S. W. A. (1987), Some aspects of the oxygen-deficient conditions and denitrification in the Arabian Sea, J. Mar. Res. 45, 1049-1072.

Naqvi, W. A., C. D. Charles and R.G. Fairbanks (1994), Carbon and oxygen isotopic records of benthic foraminifera from the northeast Indian Ocean: Implications on glacial-interglacial atmospheric $\mathrm{CO}_{2}$ changes, Earth Planet. Sci. Lett. 121, 99-110.

Naqvi, S. W. A. and R. G. Fairbanks (1996), A 27,000 year record of Red Sea outflow: Implication for timing of post-glacial monsoon intensification, Geophys. Res. Lett., 23, 1501-1504.

Naqvi, S.W.A. and S. Naik, (1983), Calcium: chlorinity ratio and carbonate dissolution in the northwestern Indian Ocean, Deep-Sea Res. (A: Oceanogr. Res. Pap.), 30, 381-392.

Neff, U., S. J. Burns, A. Mangini, M. Mudelsec, D. Fleitmann, and A. Matter (2001), Strong coherence between solar variability and the monsoon in Oman between 9 and 6 kyr ago, Nature, 411, 290-293, doi:10.1038/35077048.

Overpeck, J. T., D. M. Anderson, S. Trumbore, and W. L. Prell (1996), The southwest Indian monsoon over the last 18,000 years, Clim. Dyn., 12, 213-225, doi:10.1007/BF00211619.

Pattan, J.N., Toshiyuki Masuzawab, P.D. Naidu, G. Parthiban and Mineko Yamamoto(2003), Productivity fluctuations in the southeastern Arabian Sea during the last $140 \mathrm{ka}$, Palaeogeogr. Palaeoclimatol. Palaeoecol., 193, 575-590.

Pichevin L., E. Bard, P. Martinez and I. Billy (2007), Evidence of ventilation changes in the Arabian Sea during the last Quaternary: Implication for denitrification and nitrous oxide emission, Global Biogeochem. Cycles, 21, doi:10.1029/2006GB002852

Qasim, S. Z. (1977), Biological productivity of the Indian Ocean, Indian J Mar Sci, 6, 122-137.

Rao, V.P., P.M. Kessarkar, S.K. Patil, S.M. Ahmad (2008), Rock magnetic and geochemical record in a sediment core from the eastern Arabian Sea: Diagenetic and environmental implications during the late Quaternary, Palaeogeogr. Palaeoclimatol. Palaeoecol., 270, 46-52.

Rao, V. P., P. M. Kessarkar, M. Thamban and S. K. Patil (2010), Paleoclimatic and diagenetic history of the Late Quaternary sediments in a core from the southeastern Arabian Sea: Geochemical and magnetic signals, J. Oceanogr., 66, 133-146.

Rashid, H., B. P. Flower, R. Z. Poore and T. M. Quinn (2007), A 25 ka Indian Ocean monsoon variability record from the Andaman Sea, Quatern. Sci. Rev., 26, 2586-2597.

Rohling E. J., (2000) Paleosalinity: Confidence limits and future applications, Mar. Geol., 163, 1-11

Saher, M. H., S. J. A. Jung, H. Elderfield, M. J. Freaves and D Kroon (2007), Sea surface temperature of the western Arabian Sea during the last deglaciation, Paleoceanography , 22, PA2208, doi:10.1029/2006PA001292. 
Saji, N. H., B. N. Goswami, P. N. Vinayachandran and T. Yamagata (1999), A dipole mode in the tropical Indian Ocean, Nature, 401(6751), 360-363.

Saraswat, R., R. Nigam, S. Weldeab and A. Mackensen (2007), The tropical warm pool in the Indian Ocean and its influence on ENSO over the past 137,000 yrs BP, Curr. Sci., 92(8), 1153-1156.

Saraswat, R., R. Nigam, A. Mackensen and S. Weldeab (2012), Linkage between seasonal insolation gradient in the tropical northern hemisphere and the sea surface salinity of the equatorial Indian Ocean during the last glacial period, Acta Geol. Sin., 86, 1265-1275.

Sarkar, A., R. Ramesh,S.K. Bhattacharya and G. Rajagopalan, (1990), Oxygen isotope evidence for a stronger winter monsoon current during the last glaciations, Nature, 343, 549-551.

Schulz, M. and M. Mudelsee (2002), REDFIT: estimatingred-noise spectra directly from unevenly spaced paleoclimatic time series, Comput. Geosci., 28, 421-426

Schulz, H, U. Von Rad and H. Erlenkeuser (1998), Correlation between Arabian Sea and Greenland climate oscillations of the past 110,000 years. Nature, 939, 54-57.

Sen Gupta, R and S. W. A. Naqvi (1984), Chemical oceanography of the Indian Ocean, north of the equator. Deep-Sea Res., 31, 671-706

Sinha, A., K. G. Cannariato, L. D. Stott, H.-C. Li, C.-F. You, H. Cheng, R. L. Edwards, and I. B. Singh (2005), Variability of southwest Indian summer monsoon precipitation during the Bølling-Âllerød, Geology, 33, 813-816.

Singh, A. D., D. Kroon, and R. S. Ganeshram (2006), Millennial scale variations in productivity and OMZ intensity in the Eastern Arabian Sea, J. Geol. Soc. India, 68, 369-378.

Sirocko, F., M. Sarnthein, H. Erlenkeuser, H. Lange, M. Arnold, and J. C. Duplessy (1993), Century-scale events in monsoonal climate over the past 24,000 years, Nature, 364, 322-324, doi:10.1038/364322a0.

Sirocko, F., D. Garbe-Schonberg, A. Mclntyre and B. Molfino (1996), Teleconnections between the subtropical monsoons and high latitude climates during the last deglaciation. Science, 272, 526-529.

Sirocko, F, D. G. Schonberg and C. Devey (2000), Processes controlling trace element geochemistry of Arabian Sea sediments during the last 25,000years, Global Planet Change, 26, 217-303.

Staubwasser, M., F. Sirocko, P. Grootes and M. Segl (2003), Climate change at the 4.2 ka BP termination of the Indus valley civilization and Holocene south Asian monsoon variability, Geophys. Res. Lett. doi:10,1029/2002GL016822.

Staubwasser, M. and H. Weiss (2006), Holocene climate and cultural evolution in late prehistoric-early historic West Asia, Quatern. Res., 66, 372-387.

Steinke, S., H.-Y. Chiu, P-S. Yu, C.-C. Shen, H. Erlenkeuser, L. Lowemark and M.-T. Chen (2006), On the influence of sea level and monsoon climate on the southern South China Sea freshwater budget over the last 22,000 years, Quatern. Sci. Rev., 25, 1475-1488.

Stuiver, M., P. J. Reimer and R. W. Reimer (2005), CALIB 5.02 (program and documentation). http:/www.calib.qua.ac.uk/

Stuiver, M., T.F. Braziunas, P.M. Grootes, and G.A. Zielinski (1997), Is there evidence for solar forcing of climate in the GISP2 oxygen isotope record? Quatern. Res., 48, 259-266. 
Suthhof, A., V. Ittekkot and B. Gaye-Haake (2001), Millennial-scale oscillations of denitrification intensity in the Arabian Sea during the late Quaternary and its potential influence on atmospheric $\mathrm{N}_{2} \mathrm{O}$ and global climate, Global Biogeochem. Cycles, 15, 637-650.

Thamban, M. H. Kawahata and V. P. Rao (2007), Indian summer monsoon variability during the Holocene as recorded in sediments of the Arabian Sea: Timing and implications, J. Oceanogr., 63, 1009-1020.

Thamban, M, V. P. Rao, R. R. Schneider and P. M. Grootes (2001), Glacial to Holocene fluctuations in hydrography and productivity along the southwestern continental margin of India, Palaeogeogr. Palaeoclimatol. Palaeoecol., 165, 113-127.

Thamban, M., V. P. Rao and R. R. Schneider (2002), Reconstruction of late Quaternary monsoon oscillations based on clay mineral proxies using sediment cores from the western margin of India, Mar. Geol., 186, 527-539.

Tiwari, M, R. Ramesh, R. Bhushan, M. S. Sheshshayee, B. L. K. Somayajulu, A. J. T. Jull and G. S. Burr (2010), Did the Indo-Asian summer monsoon decrease during the Holocene following insolation?, J. Quatern. Sci., doi: 10.1002/jqs.1398

Tiwari, M., R. Ramesh, B. L. K. Somayajulu, A. J. T. Jull, and G. S. Burr (2005), Early deglacial ( 19-17 ka) strengthening of the northeast monsoon, Geophys. Res. Lett., 32, L19712, doi:10.1029/2005GL024070.

Van Campo, E., P. Cour and H. Sixuan (1996), Holocene environmental changes in Bangong Co basin (Western Tibet). Part 2: The pollen record, Palaeogeogr. Palaeoclimatol. Palaeoecol., 120, 49-63

Waelbroeck, C., L. Labeyrie, E. Michel, J.C. Duplessy, J.F. McManus, K. Lambeck, E. Balbon and M. Labracherie (2002), Sea-level and deep water temperature changes derived from benthonic foraminifera isotopic records, Quatern. Sci. Rev., 21,295-305.

Wang, Y. J., H. Cheng, R. L., Z. S. An, J. Y. Wu, C.-C. Shen and J. A. Dorale (2001), A high-resolution absolutedated late Pleistocene monsoon record from Hulu Cave, China, Science, 294, 2345-2348, doi: 10.1126/science.1064618.

Wang, F.-B. and C. Y. Fan (1987), Climatic changes in the Qinghai-Xizang (Tibetan) region of China during the Holocene, Quatern. Res., 28, 50-60.

Wang, P., S. Clemens, L. Beaufort, P. Braconnot, G. Ganssen, Z. Jian, P. Kershaw and M. Sarnthein (2005), Evolution and variability of the Asian monsoon system: state of the art and outstanding issues, Quatern. Sci. Rev., 24, 595-629.

Wyrtki, K. 1971, Oceanographic Atlas of the International Indian Ocean Expedition, National Science Foundation, Washington DC. pp. 531. 


\section{Caption for the Figures}

Figure 1 (A-C) Monthly average of Rainfall, (D-F Monthly average freshwater influx (EvaporationPrecipitation) [Fennig et al., 2013]). Note that there is increase in freshwater flux on the southwestern margin of India during the southwest monsoon. (G) Thick circles are core locations showing the core AAS62/1, AAS62/2 [Rao et al., 2008], SK148/4 [Rao et al., 2010], SK17 [Singh et al., 2006] numbers in the brackets are water depth. Inset figure shows location of core AAS62/1, Timta and Hulu caves, contours of onset dates of Indian summer monsoon. Thick lines indicate Indian and Asian monsoon trajectories [modified after, Sinha et al., 2010].

Figure $2(\mathrm{~A})$ Calibrated radiocarbon ages and sedimentation rates (cm/ka). (B-E) Variations in $\delta^{18} \mathrm{O}_{\mathrm{C}}(G$. ruber) in the southeastern Arabian Sea, (B) Core locations, (C) surface values, (D) between 5.67 ka BP when monsoon was stable (E) 11-12 ka BP were there was abrupt event of ISM monsoon, data points were taken based on the available analysis during these time frames (see Table 2).

Figure 3 Temporal variations in the $\delta^{18} \mathrm{O}_{\mathrm{C}}$ record of $\mathrm{G}$. ruber, $\delta^{15} \mathrm{~N}$ of $\mathrm{C}_{\text {org }}$, Sea surface temperature (SST) in ${ }^{\circ} \mathrm{C}, \quad \delta^{18} \mathrm{O}_{\mathrm{W}}$, Sea surface salinity (SSS) $\mathrm{C}_{\text {org, }} \mathrm{CaCO}_{3}$ content and grain size of land derived material. ISM-Indian summer monsoon, B-A- Bølling-Ållerød, YD- Younger Dryas, AEabrupt ISM event, Grey bends indicate intensification of ISM. Vertical short bar denotes estimated error.

Figure 4 Comparison of $\delta^{18} \mathrm{O}_{\mathrm{C}}$ records from the southeastern Arabian sea SK148/4 [Rao et al., 2010]; AAS 62/1 (present study) vertical short lines are AMS ages of this core; AAS62/2 [Rao et al., 2008] vertical doted lines are AMS ages of this core; SK17 [Singh et al., 2006],

Figure 5 Comparison of $\delta^{18} \mathrm{O}_{\mathrm{C}}$ of AAS 62/1 with the methane content of GISP2 core and June solar Insolation maximum at $30^{\circ} \mathrm{N}$

Figure 6 Comparison of $\delta^{18} \mathrm{O}_{\mathrm{C}}$ of AAS 62/1, with $\delta^{18} \mathrm{O}$ of GISP2 (Bidecadal Oxygen Isotope Data), Timta and Hulu caves [Stuiver et al., 1997; Sinha et al., 2005; Wang et al., 2001]. Grey bands indicate intensification of the ISM.

Figure 7 Power spectra of oxygen isotope time series of $G$. ruber. Horizontal line on the upper right shows $6 \mathrm{db}$ bandwidth, doted line indicates $95 \%$ confident line. 
Table 1. Accelerator Mass Spectrometer (AMS) ages of sediment intervals dated in the core AAS-62/1

\begin{tabular}{cccc}
\hline $\begin{array}{l}\text { Depth } \\
\text { interval in the } \\
\text { core }(\mathrm{cm})\end{array}$ & $\begin{array}{l}\text { Lab code at } \\
\text { WHOI }\end{array}$ & $\begin{array}{l}\text { Radiocarbon Age } \\
\text { (years B.P.) }\end{array}$ & $\begin{array}{l}\text { Calibrated } \\
\text { Age Range } \\
\text { (Years B.P.) }\end{array}$ \\
\hline & & & \\
$6-8$ & 57869 & $1770 \pm 35$ & 1177 \\
$18-20$ & 50064 & $2720 \pm 40$ & 2252 \\
$40-42$ & 57870 & $3180 \pm 35$ & 2848 \\
$54-56$ & 57871 & $4510 \pm 25$ & 4552 \\
$74-76$ & 50065 & $6420 \pm 45$ & 7347 \\
$120-125$ & 57872 & $9520 \pm 45$ & 10268 \\
$170-175$ & 50066 & $10500 \pm 60$ & 11463 \\
$270-275$ & 50067 & $11050 \pm 55$ & 12476 \\
$340-345$ & 50068 & $12400 \pm 75$ & 13690 \\
$495-500$ & 54961 & $14450 \pm 65$ & 16569 \\
\hline
\end{tabular}


Table 2a. Location of cores and $\delta^{18} \mathrm{O}_{\mathrm{C}}$ (G. ruber) values at different time intervals that are used in Figure 2.

*Values were extracted from the figures. \#Average values for 11-12 ka BP in cores AAS62/1 and AAS62/2

\begin{tabular}{|c|c|c|c|c|c|}
\hline & Core & & & Age ka BP & $\begin{array}{l}\delta^{18} \mathrm{O}_{\mathrm{C}} \%(\mathrm{G} . \\
\text { ruber) }\end{array}$ \\
\hline \multirow{2}{*}{$\begin{array}{l}\text { Saraswat et al., } \\
\text { [2012] }^{*}\end{array}$} & SK157/4 & $2^{\circ} 40^{\prime} \mathrm{N}$ & $78^{\circ} 00^{\prime} \mathrm{E}$ & Surface & -1.9 \\
\hline & & & & $\begin{array}{l}6 \\
11.1\end{array}$ & $\begin{array}{l}-2.0 \\
-2.18\end{array}$ \\
\hline \multirow{3}{*}{$\begin{array}{l}\text { Tiwari et al., } \\
{[2005]^{*}}\end{array}$} & SS3827G & $3^{\circ} 42^{\prime} \mathrm{N}$ & $75^{\circ} 54.5^{\prime} \mathrm{E}$ & Surface & -2.7 \\
\hline & & & & 6 & -2.5 \\
\hline & & & & 12 & -1.6 \\
\hline \multirow[t]{3}{*}{ Rao et al., [2010] } & SK148/4 & $8^{\circ} 12^{\prime}$ & $75^{\circ} 54^{\prime}$ & Surface & -2.9 \\
\hline & & & & 5.6 & -2.5 \\
\hline & & & & 12 & -1.8 \\
\hline \multirow{3}{*}{$\begin{array}{l}\text { Pattan et al., } \\
{[2003]^{*}}\end{array}$} & $\begin{array}{l}\text { SK129/CR- } \\
05\end{array}$ & $9^{\circ} 21^{\prime} \mathrm{N}$ & $71^{\circ} 59^{\prime} \mathrm{E}$ & Surface & -2.5 \\
\hline & & & & 6 & -2.5 \\
\hline & & & & 11.5 & -0.95 \\
\hline \multirow{3}{*}{$\begin{array}{l}\text { Thamban et al., } \\
{[2001]^{*}}\end{array}$} & GC5 & $10^{\circ} 23^{\prime}$ & $75^{\circ} 34^{\prime}$ & Surface & -3 \\
\hline & & & & 5.6 & -2.5 \\
\hline & & & & 12 & -1.5 \\
\hline Sarkar et al., 1990 & SK-20-185 & $10^{\circ} \mathrm{N}$ & $71^{\circ} 50^{\prime} \mathrm{E}$ & Surface & -1.85 \\
\hline \multirow[t]{3}{*}{ Present study } & AAS62/1 & $11^{\circ} 30^{\prime} \mathrm{N}$ & $74^{\circ} 37^{\prime} \mathrm{N}$ & Surface & -3 \\
\hline & & & & & -3 \\
\hline & & & & $\begin{array}{l}11.8 \\
11-12^{\#}\end{array}$ & $\begin{array}{l}3.3 \\
(2.2)^{\#}\end{array}$ \\
\hline
\end{tabular}



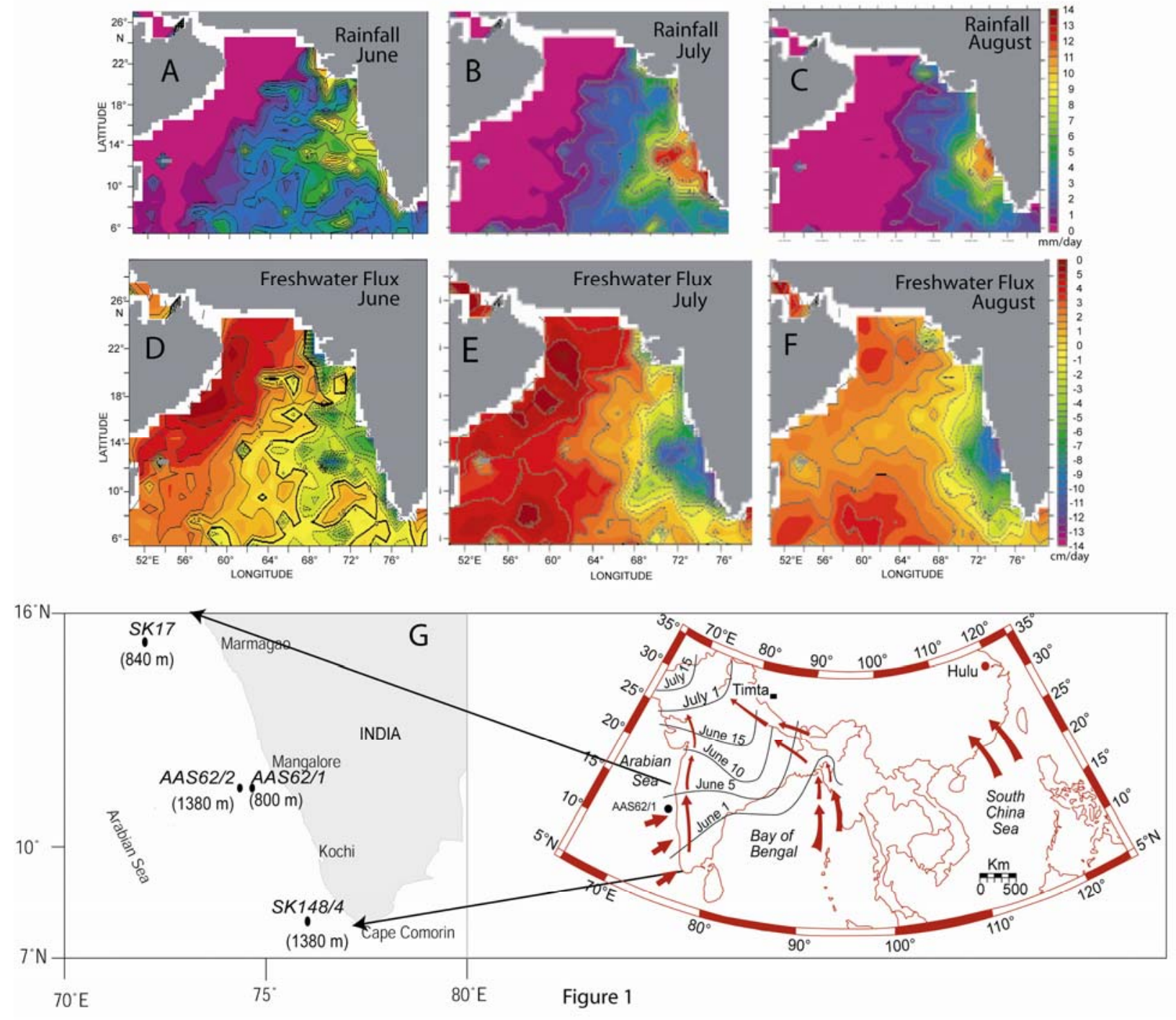

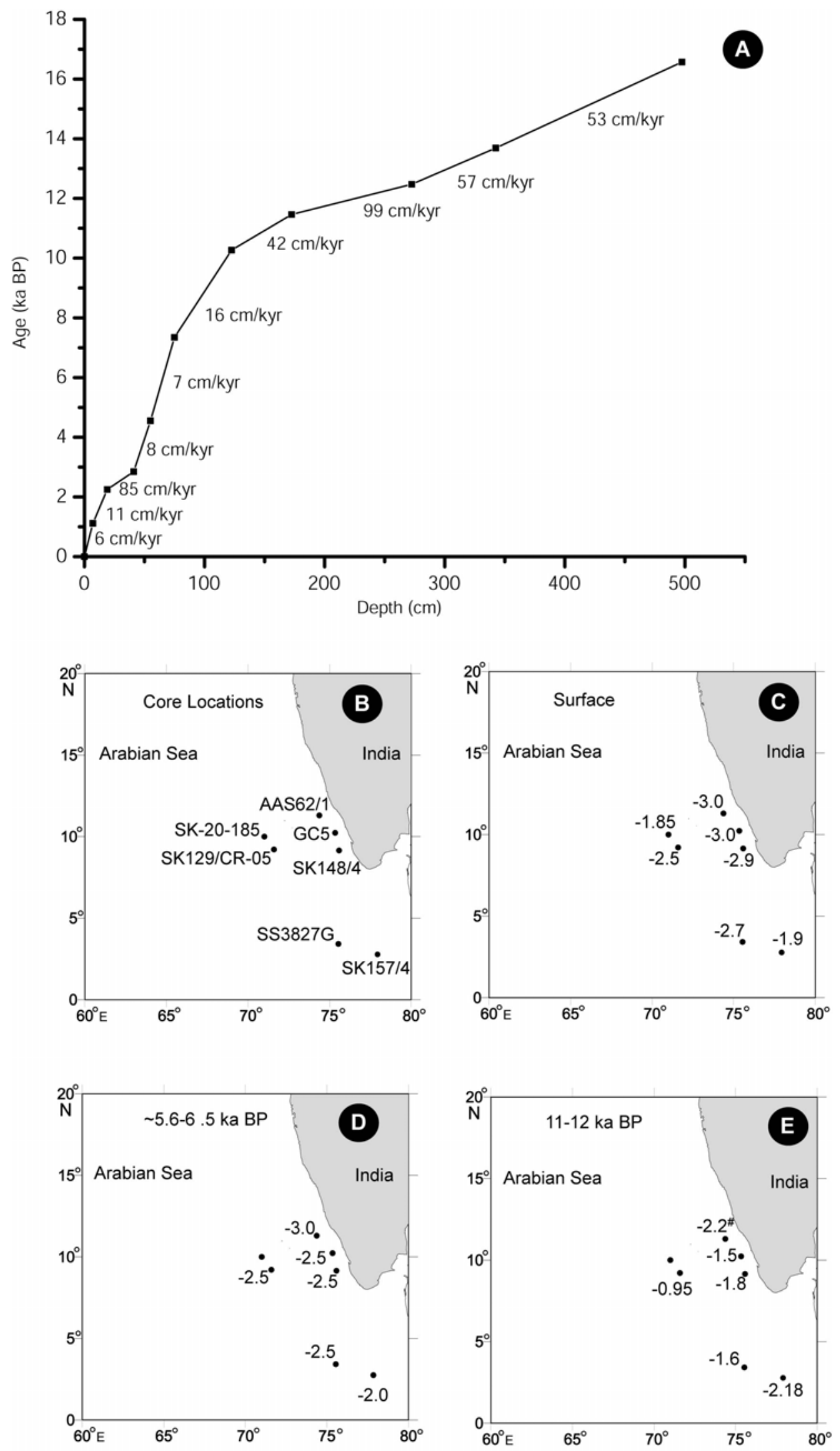

Figure 2 


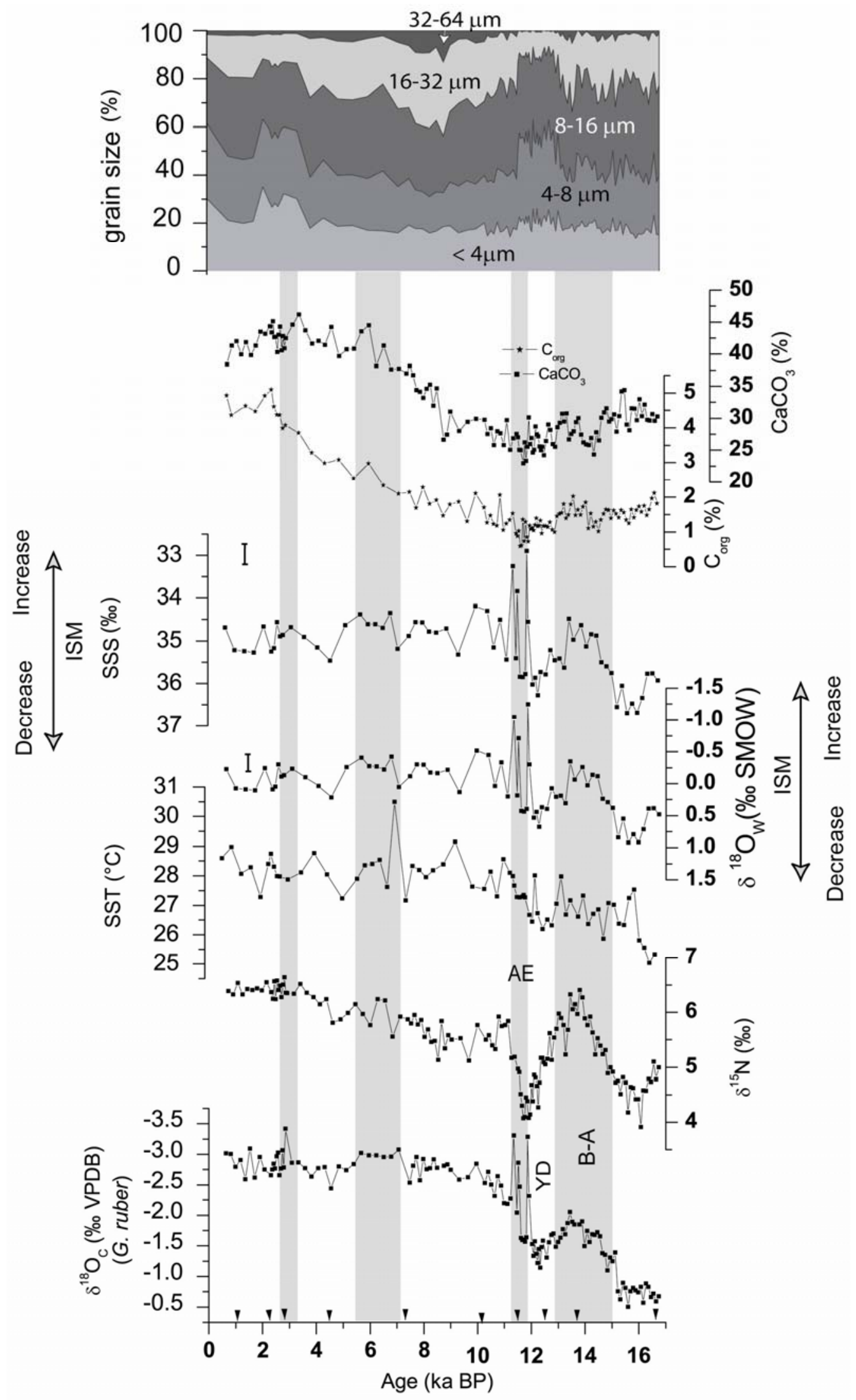

Figure 3 


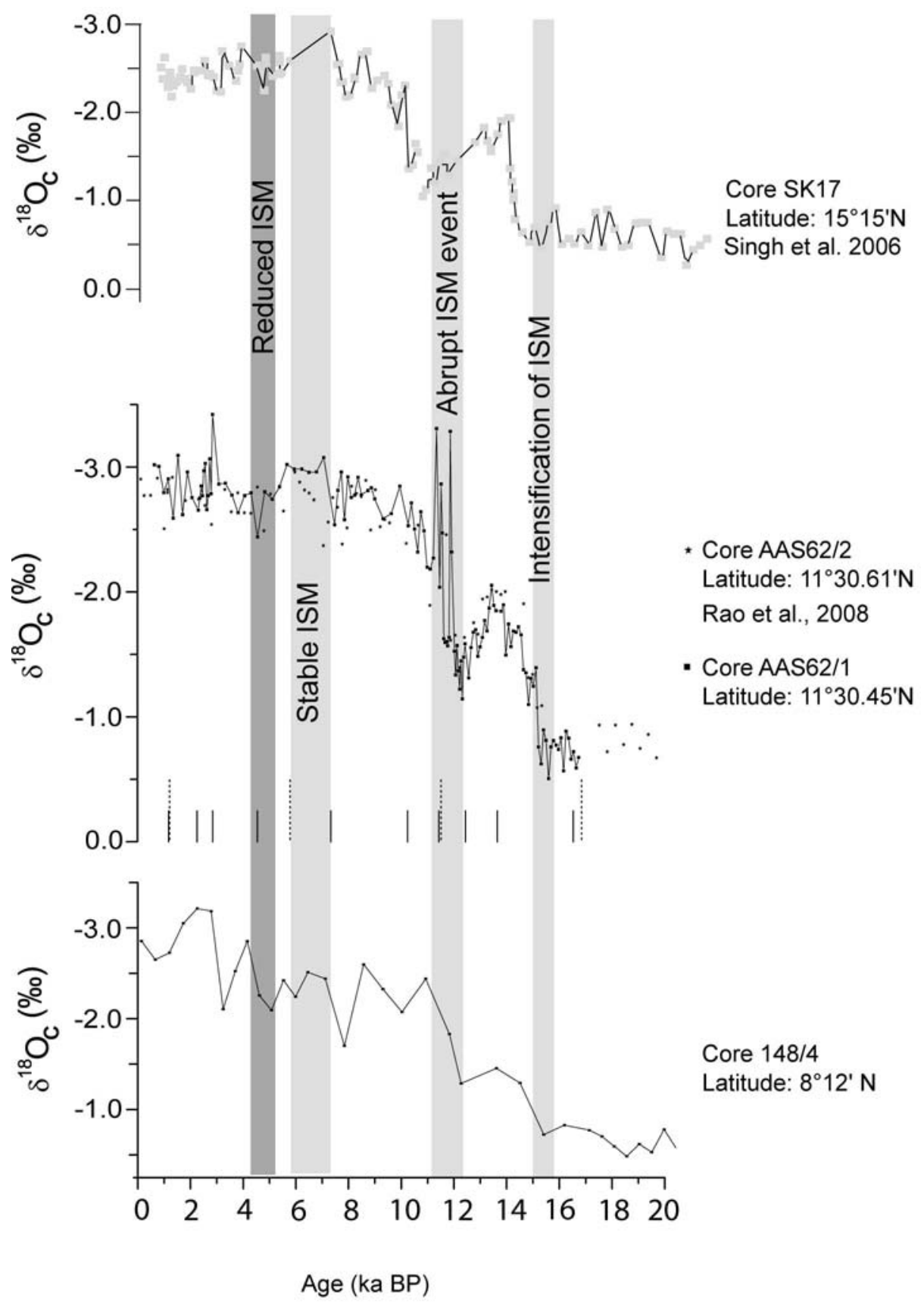

Figure 4 


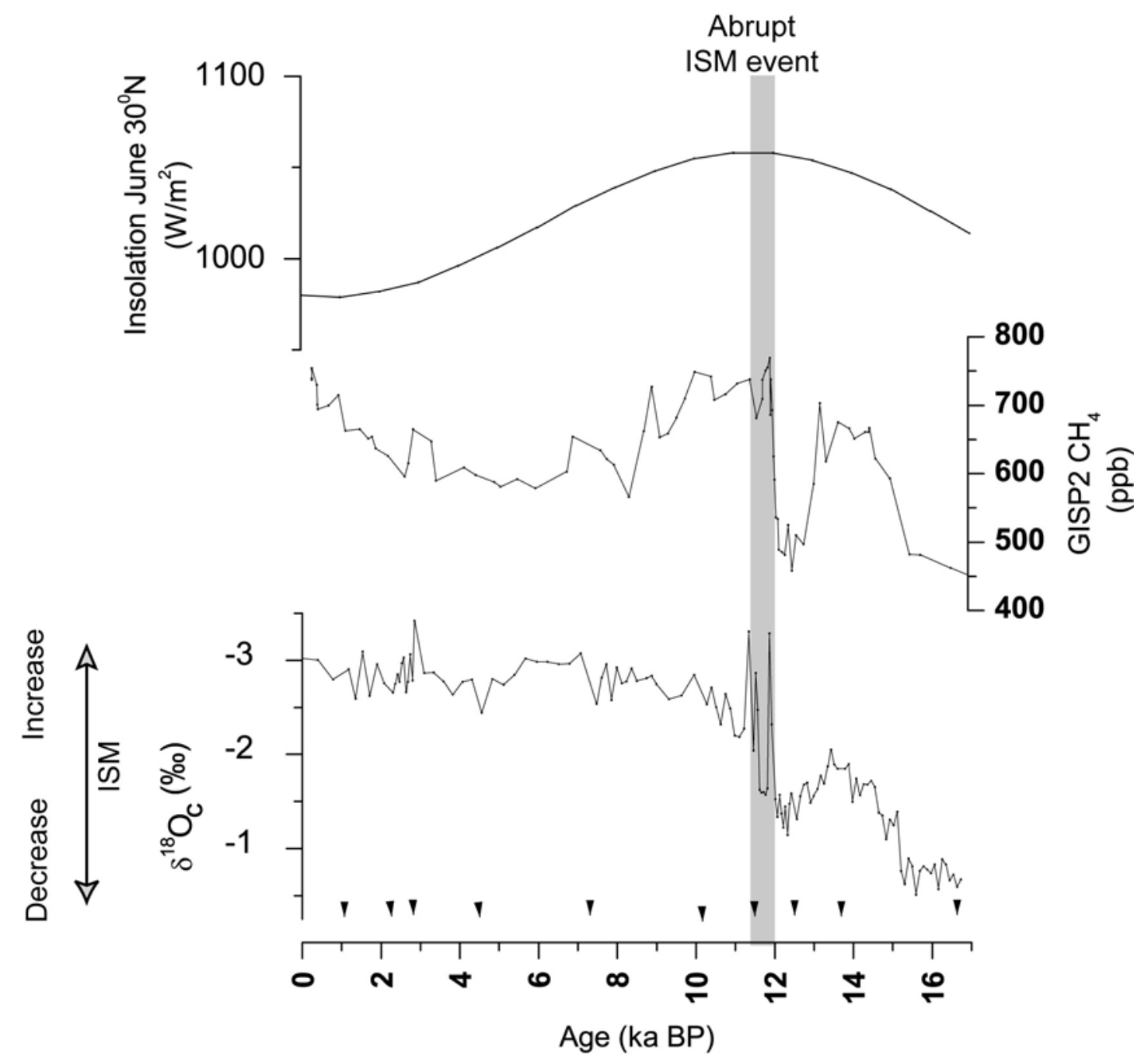

Figure 5 


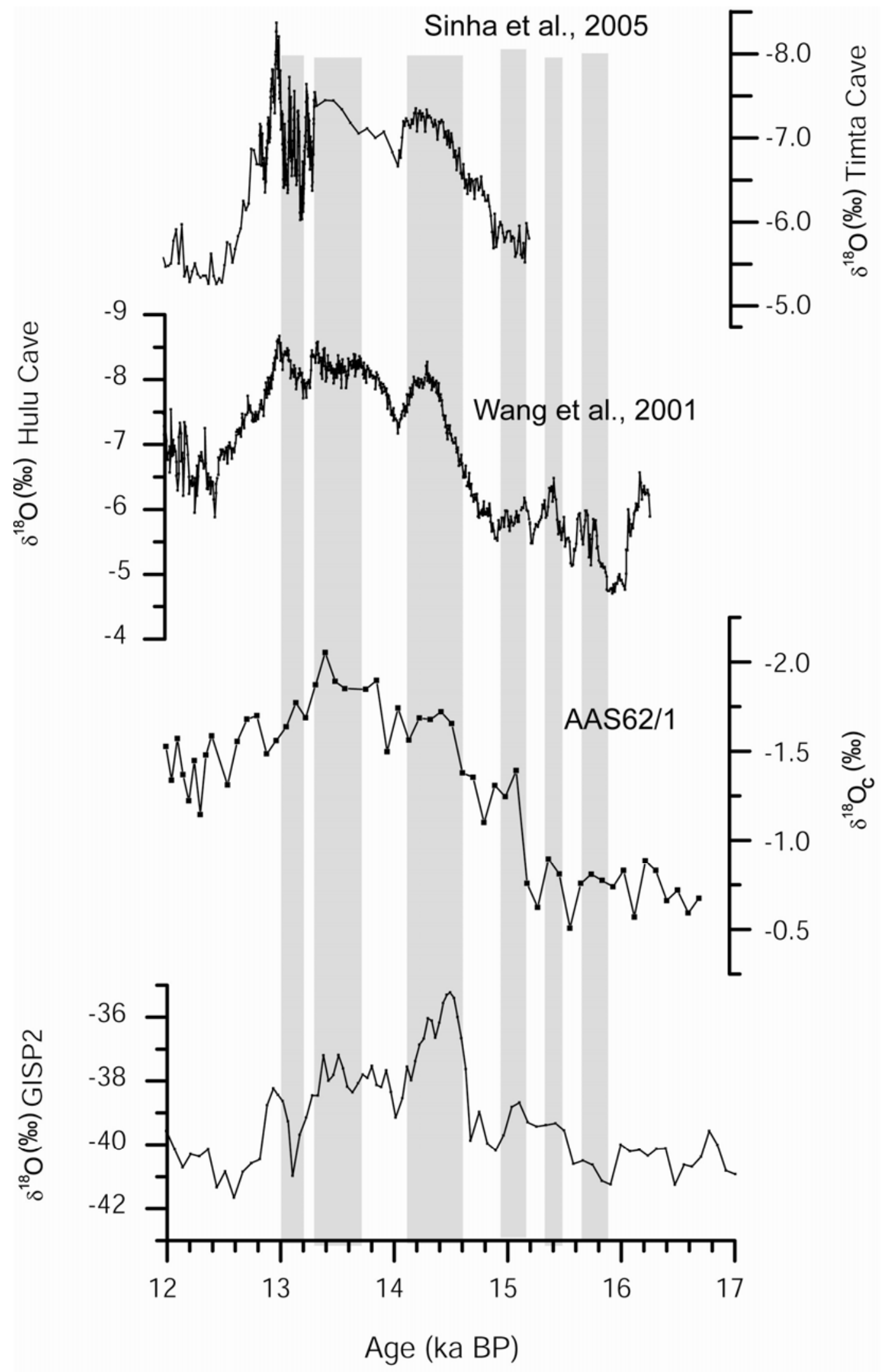

Figure 6 


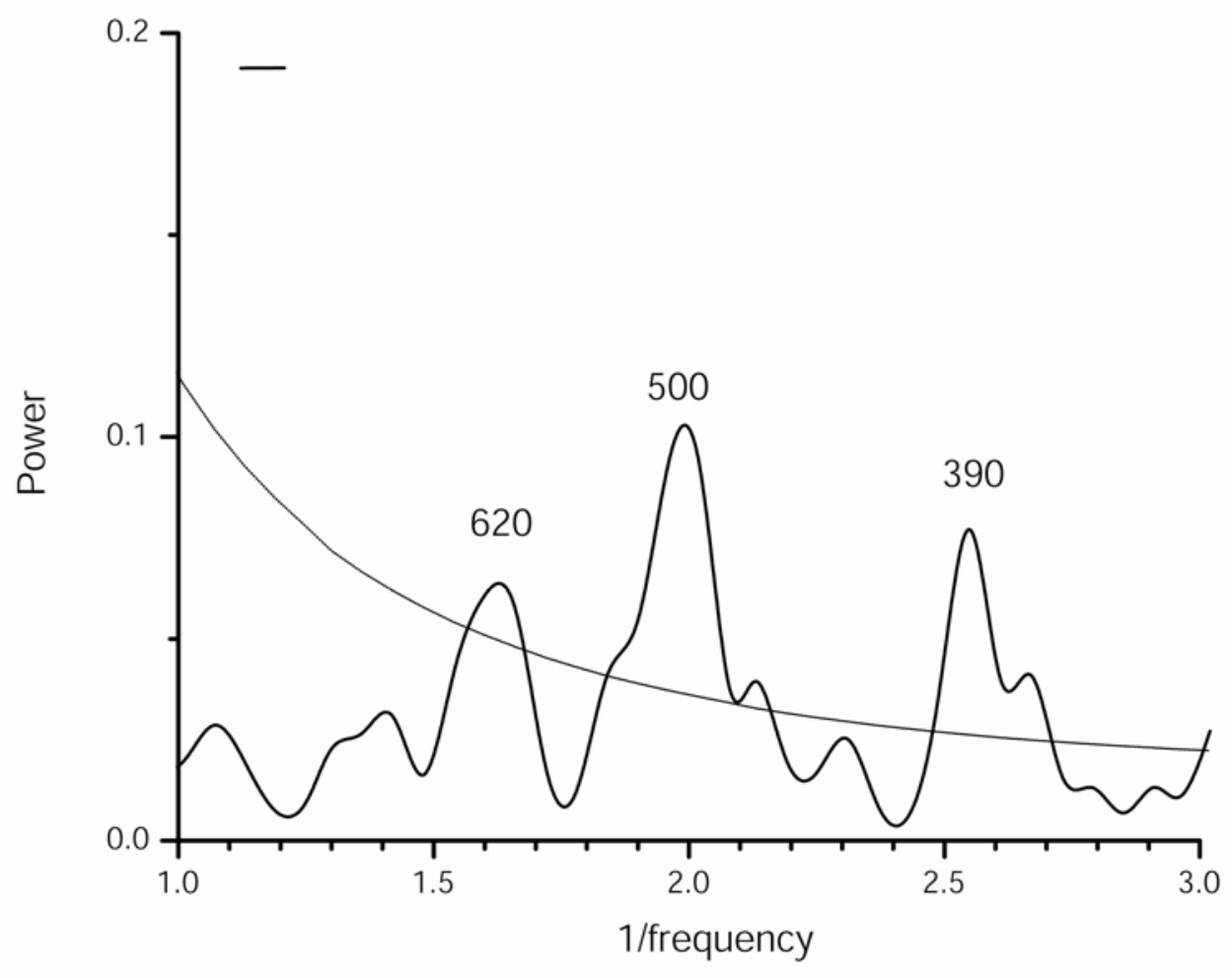

Figure 7 